\title{
Charcot-Marie-Tooth disease type 4C
}

INSERM

\section{Source}

INSERM. (1999). Orphanet: an online rare disease and orphan drug data base. CharcotMarie-Tooth disease type 4C. ORPHA:99949

Charcot-Marie-T ooth disease type 4C (CMT 4C) is a subtype of Charcot-Marie-Tooth type 4 characterized by childhood or adolescent-onset of a relatively mild, demyelinating sensorimotor neuropathy that contrasts with a severe, rapidly progressing, early-onset scoliosis, and the typical CMT phenotype (i.e. distal muscle weakness and atrophy, sensory loss, and often foot deformity). A wide spectrum of nerve conduction velocities are observed and cranial nerve involvement and kyphoscoliosis have also been reported. 